BMJ

Open

Gastroenterology

\title{
Prevalence of hepatitis B seromarkers and hepatitis $C$ antibodies in blood donors in Basra, Iraq
}

\author{
Ali Al-Rubaye, ${ }^{1}$ Ziad Tariq, ${ }^{2}$ Laith Alrubaiy, ${ }^{3}$
}

To cite: Al-Rubaye A, Tariq Z, Alrubaiy $L$. Prevalence of hepatitis B seromarkers and hepatitis $C$ antibodies in blood donors in Basra, Iraq. BMJ Open Gastro 2016;3: e000067. doi:10.1136/ bmjgast-2015-000067

Received 14 October 2015 Revised 22 November 2015 Accepted 10 December 2015

'Basra General Hospital,

Basra, Iraq

2Director of the department of public health, Basra, Iraq ${ }^{3}$ College of Medicine, Swansea University, Swansea, UK

Correspondence to Dr Ali Al-Rubaye; akq.alrubaye@gmail.com

\section{ABSTRACT}

Background: Transfusion-caused hepatitis remains a major problem in Iraq. Therefore, testing for hepatitis B surface antigen $(\mathrm{HBsAg})$, antibodies to hepatitis B core antigen (anti-HBc) and antibodies to hepatitis $\mathrm{C}$ antigen (anti-HCV) is a very important preventative measure. The objective of this study was to establish the prevalence of hepatitis $B$ and $C$ virus seromarkers among blood donors as a foundation for safe blood transfusion in Iraq.

Methods: A cross-sectional observational study was conducted in the blood banks in Basra, Iraq from 1 January to 31 December 2013. Blood samples were collected and were tested for $\mathrm{HBsAg}$, anti-HBc and anti-HCV using standard laboratory techniques.

Results: A total of 69915 blood donors were enrolled for the study. A total of 1625 (2.3\%) donors have shown serological evidence for hepatitis $B$ virus infection; of those donors, $125(0.2 \%)$ showed a positive test result for both anti-HBc and $\mathrm{HBsAg}$ while $1475(2.1 \%)$ had positive anti-HBc results as the only positive test for HBV infection. There was no significant difference between males and females $(p=0.28)$. The prevalence of anti-HCV was $0.1 \%$.

Conclusions: This is the first large population study of its kind in Basra, Iraq. The prevalence of hepatitis B and $\mathrm{C}$ among blood donors is very low in Basra. Around $2 \%$ of blood donors had anti-HBc as the only serological evidence of HBV infection. Inclusion of anti$\mathrm{HBc}$ in routine screening of blood donors in Iraq should be encouraged.

\section{INTRODUCTION}

Hepatitis B virus (HBV) infection is the 10th leading cause of death globally with up to 1.2 million deaths each year. ${ }^{1}$ There are approximately 2 billion people infected worldwide. Around 350 million are chronic carriers of HBV. $^{2}$ Long-term complications of hepatitis $\mathrm{B}$ include cirrhosis, liver failure or hepatocellular carcinoma (HCC). ${ }^{3}$

Transfusion-related $\mathrm{HBV}$ infection remains a big problem in developing countries where safe blood transfusion has not been established until recently. ${ }^{4}$ Testing for hepatitis B

\section{Summary box}

What is already known about this subject?

- Transfusion-related hepatitis B infection remains a big problem in developing countries.

- Long-term complications of hepatitis B include cirrhosis, liver failure or hepatocellular carcinoma.

What are the new findings?

- The prevalence of hepatitis B infection and hepatitis $C$ infection in blood donors in Basra is relatively low compared to other Iraqi governorates and other countries.

- In screening for HBV infection, testing for antihepatitis $B$ core antigen $(\mathrm{HBc})$ antibody test can detect infected donors who are negative for hepatitis B surface antigen.

How might this impact on clinical practice in the foreseeable future?

- The importance of anti-HBc antibody testing remains the main strategy to identify all donors with occult HBV infection as it remains positive for life.

surface antigen (HBsAg) is the commonly used screening test in developing countries. However, screening blood for HBsAg does not rule out the risk of transmission of hepatitis B totally, because during the core window period the HBsAg cannot be detected in the blood, despite the fact that $\mathrm{HBV}$ infection is present. During this phase, the antibody to the hepatitis B core antigen (anti-HBc) can be used as a useful serological marker for $\mathrm{HBV}$ infection. ${ }^{5}$ Blood units collected from individuals with chronic $\mathrm{HBV}$ infection where $\mathrm{HBsAg}$ is not detected or in individuals with acute hepatitis B who are in the window phase have to be tested for anti-HBc. It was suggested that anti-HBc screening of blood donations might prevent HBV transmission from HBsAg-negative blood donors. $^{2} 3{ }^{6}$ It was for these reasons that blood banks in Iraq have incorporated anti-HBc testing in their donor screening 
protocols. However, the only reliable way to rule out HBV infection is by testing for HBV DNA using more advanced techniques for Nucleic Acid Testing (NAT) such as TMA (Transcription Mediated Amplification) or PCR, which are able to amplify and detect the HBV DNA. Using these techniques has greatly enhanced the accuracy of detecting HBV infection. However, being a developing country, Iraq cannot afford to screen all donors' blood for HBV DNA.

In Iraq, HBV infection has declined in the past few decades. Hepatitis B in blood donors was $3.6 \%$ in 1973 , $4.1 \%$ in 1984 to less than $1 \%$ in the nineties. ${ }^{7} 8$ This reduction is the result of the prevention and control programmes adopted by the government, such as safe blood transfusion and safe injections in addition to introduction of the vaccination programme. The aim of the present study was therefore to examine the prevalence of HBV and HCV seromarkers among potential blood donors in Basra, which is the second largest city in Iraq.

\section{MATERIALS AND METHODS}

The required ethics and governmental approval was sought before starting the study. In the Basra governorate, there are only two blood banks in which the blood donation is exclusively performed; both of them are regulated by the department of health; they are the Basra Central Blood Bank (in Basra city centre) and the Al-Qurna Blood Bank (in Al-Qurna district). All blood donors are routinely screening for the presence of serological evidence of HBV and HCV infection. Demographic data which included age and sex were collected from the records of these two blood banks. A convenience sample of all blood donors during the study period from 1 January to 31 December 2013 was included in the study. All age groups and both sexes were invited for the study. Informed consent was taken following full explanation of the study. Exclusion criteria were very ill donors with chronic comorbidities, donors who could not give their consent for the study or those who did not give their consent.

Five millilitres of blood was collected from each donor and was stored at $2-6^{\circ}$ until tested as per the blood banks and kits manufacturers' recommendations. Testing is always performed on the same day. Blood samples were tested for HBsAg, antibodies to anti-HBc and antibodies to hepatitis $\mathrm{C}$ antigen (anti-HCV) by the ELISA kit (BioKits). Statistical analysis was carried out using SPSS software licensed to Swansea University, UK.

\section{RESULTS}

We have received 69915 blood donations in Basra governorate (69658 males and 257 females); all of them underwent screening for HBV and HCV infections. The age of the participants ranged from 18 to 70 years (median 34 years). Positive HBV testing was higher in female than male donors but it was not statistically significant $(\mathrm{p}=0.28$; table 1$)$. A total of $1712(2.5 \%)$ donors were found to have at least one positive screening test result.

Regarding the screening for HBV, 1625 (2.3\%) donors have shown serological evidence for $\mathrm{HBV}$ infection; $1600(2.3 \%)$ donors had positive test results for anti-HBc, and $150(0.2 \%)$ donors had positive test results for HBsAg. Of those donors, $125(0.2 \%)$ showed a positive test result for both anti-HBc and HBsAg while $1475(2.1 \%)$ had positive anti-HBc results as the only positive test for HBV screening (tables 1 and 2). For the screening for HCV infection, $87(0.1 \%)$ blood donors showed a positive test result for the anti-HCV antibody (table 1).

\section{DISCUSSION}

The prevalence of hepatitis infection in the general population in Iraq is not available due to the unstable political and social situation for the past decades. To the best of our knowledge, the only published data on the prevalence of viral hepatitis in Iraq are from blood donor studies. Hepatitis seromarkers are important tests in screening blood donors and prevent transfusion-related hepatitis. Testing for HbsAg may not identify donors with occult HBV infection who have isolated anti-HBc antibodies. Anti-HBc remains positive lifelong in all the donors with an HBV infection in the past. Therefore, most anti-HBc positives will have anti-HBs positive as a sign of infection in the past. However, it remains useful to screen for anti-HBc, since for the purpose of blood transfusion it is better to exclude all anti-HBc-positive donors to prevent transfusion-related HBV infection.

Transfusion of blood collected from a donor who is in the window period may lead to post-transfusion hepatitis $\mathrm{B}$ in the recipient. ${ }^{9}{ }^{10}$ Anti-HBc has been found to be an excellent indicator of occult $\mathrm{HBV}$ infection during the window period. ${ }^{9} 1112$ Detection of anti-HBc has contributed significantly in reducing the incidence of posttransfusion hepatitis B infection. ${ }^{6}{ }^{13}{ }^{14}$ However, the best reliable testing for HBV infection is the HBV DNA by PCR ${ }^{15}$ Previous studies have demonstrated the presence of HBV DNA in anti-HBc-only donors. ${ }^{5}{ }^{16}$ However, in countries with limited resources such as Iraq, testing for HBV DNA is not cost-effective. Since the 1970s, blood banks in Iraq have incorporated anti-HBc testing in their donor screening protocols. ${ }^{8}$

Control and prevention strategies for hepatitis $\mathrm{C}$ have assumed great importance since vaccine for chronic hepatitis $\mathrm{C}$ is unavailable. In addition to that, treatment for such infection is very expensive. Thus, from a global perspective, the greatest impact on hepatitis $\mathrm{C}$ disease burden will most likely be achieved by reducing the risk of HCV transmission from nosocomial exposure (blood transfusion, unsafe injection practices) and high-risk behaviour (injection drug use).

Our study indicates that testing blood donors for HBsAg alone is not sufficient to eliminate HBV from the 
Table 1 Age and sex distribution of donors and their test results

\begin{tabular}{|c|c|c|c|c|c|c|}
\hline \multirow[b]{3}{*}{ Age } & \multicolumn{4}{|l|}{ Donor's sex } & \multirow{3}{*}{$\begin{array}{l}\text { Donors with } \\
\text { positive results (\%) }\end{array}$} & \multirow[b]{3}{*}{ Total tested } \\
\hline & \multicolumn{2}{|c|}{ (69 658) Male donors } & \multicolumn{2}{|c|}{ (257) Female donors } & & \\
\hline & Positive HBV & Positive HCV & Positive HBV & Positive HCV & & \\
\hline$<20$ & 28 & 3 & 1 & 0 & $32(0.8)$ & 4180 \\
\hline 20-30 & 347 & 20 & 1 & 0 & $368(2.7)$ & 13869 \\
\hline $30-40$ & 664 & 35 & 3 & 0 & $702(2.7)$ & 25615 \\
\hline $40-50$ & 362 & 17 & 2 & 0 & $381(2.7)$ & 14288 \\
\hline $50-60$ & 192 & 8 & 1 & 0 & $201(2.6)$ & 7646 \\
\hline$>60$ & 23 & 4 & 1 & 0 & $28(0.7)$ & 4317 \\
\hline \multirow[t]{3}{*}{ Total } & $1616(2.3 \%)$ & $87(0.1 \%)$ & $9(3.5 \%)$ & $0(0 \%)$ & $1712(2.5)$ & 69915 \\
\hline & \multirow{2}{*}{\multicolumn{2}{|c|}{$\begin{array}{l}\text { The total number of male donors } \\
\text { with positive results is } 1703 \\
(2.4 \%)\end{array}$}} & \multirow{2}{*}{\multicolumn{2}{|c|}{$\begin{array}{l}\text { The total number of female } \\
\text { donors with positive test results } \\
\text { is } 9(3.5 \%)\end{array}$}} & \multicolumn{2}{|c|}{$\begin{array}{l}\text { The total number of donors with } \\
\text { HBV positive is } 1625(2.3)\end{array}$} \\
\hline & & & & & \multicolumn{2}{|c|}{$\begin{array}{l}\text { The total number of donors with } \\
\text { HCV positive is } 87(0.1)\end{array}$} \\
\hline
\end{tabular}

blood supply. ${ }^{17}$ The prevalence of HBsAg in blood donors in Basra is lower than in the rest of the country. In Baghdad, a cross-sectional study showed that the prevalence of HBsAg in blood donors attending the National Blood bank was $0.6 \%$ in all donors, being higher in men $(0.8 \%)$ than in women $(0.5 \%) .^{7}$ Another cross-sectional observational study in Babylon governorate showed the prevalence of HBsAg among all blood donors to be $0.7 \%$, being higher in women $(4.6 \%)$ than in men $(0.7 \%){ }^{8}$ Another study showed the prevalence of HBsAg to be $0.66 \%$ in Najaf governorate and $3.5 \%$ in Karbala. $^{18}$

Regarding results from other countries, in Kuwait, a cross-sectional study performed in 2002 found that the prevalence of $\mathrm{HBsAg}$ in Kuwaiti national donors was $1.1 \%$ while its prevalence in non-Kuwaiti donors was 3.5\% ${ }^{19}$ In Jordan, a retrospective study carried out at Prince Rashed Ben Al-Hassan Hospital in the northern region of Jordan showed the prevalence of HBsAG to be $1.4 \%$. The prevalence was higher in male than in female donors $(1.5 \%$ vs $0.5 \%) .^{20}$

Our study showed that the prevalence of HCV antibodies was $0.12 \%$ among blood donors, all of whom were males. Comparing the result of this study with the results of studies from other Iraqi governorates, Basra has a lower prevalence of $\mathrm{HCV}$ infection in blood donors. In Baghdad, the prevalence was found to be $0.7 \%$ according to a retrospective cross-sectional observational study during the years 2006-2009. ${ }^{7}$ In Babylon governorate, a cross-sectional study of blood donors from February 2007 to February 2008 showed that the prevalence of anti-HCV antibody in blood donors was $0.5 \%$. $^{8}$

On comparison with other countries, the prevalence of anti-HCV among Kuwaiti national and non-Kuwaiti Arab first-time donors was found to be 0.8 and $5.4 \%$, respectively. ${ }^{19}$ In Jordan, a hospital-based study showed that the infection with HCV among blood donors was $0.9 \% .^{20}$

Our study will provide a useful ground for comparison in future studies. To the best of our knowledge, this is the first large-scale study to examine the prevalence of seromarkers in blood donors in Basra city. However, there are some limitations to this study, due to the lack of information such as the history of blood transfusion, dental extraction, surgical operation, cupping and tattooing. Future studies will be needed to explore these areas.

One possible limitation of the study is that it included only blood donors, and this may not reflect the real prevalence in the whole society. However, we consider this as the first step in obtaining a nationwide prevalence study once the situation allows more extensive data to be collected. This approach of recruiting blood donors was used in developed countries in Europe. ${ }^{21}$

Considering the resource limitations in many areas in our country, it may not be possible or practical to provide facilities for advanced tests like HBV DNA in order to determine the best approach to prevent hepatitis

Table 2 Hepatitis B seromarkers of all blood donors

\section{Screening test for hepatitis B}

\begin{tabular}{|c|c|c|c|c|}
\hline \multirow[b]{2}{*}{ Tests } & & \multicolumn{2}{|l|}{ HBsAg } & \multirow[b]{2}{*}{ Total (\%) } \\
\hline & & Positive (\%) & Negative (\%) & \\
\hline \multirow[t]{2}{*}{$\mathrm{HBcAb}$} & Positive (\%) & $125(0.2)$ & $1475(2.1)$ & 1600 (2.3) \\
\hline & Negative (\%) & $25(0.03)$ & $68290(97.7)$ & $68315(97.7)$ \\
\hline Total (\%) & & $150(0.2)$ & 69765 (99.8) & $69915(100)$ \\
\hline
\end{tabular}

$\mathrm{HBcAb}$, hepatitis B core antibodies; HBsAg, hepatitis B surface antigen. 
infection. We recommend further studies to assess the prevalence of HBV and HCV infections in the next few years. Useful methods for prevention and control of hepatitis infection include health educational programmes about these infectious disease and provision of vaccine for vulnerable groups and modern investigation to detect these diseases in primary healthcare centres. This will help to provide support to health institutions and specifically to blood banks to help them detect and control blood-borne diseases.

\section{CONCLUSION}

The prevalence of HBV and HCV infection in blood donors in Basra is relatively low as compared to other Iraqi governorates and other countries. HBV infection is more prevalent than HCV infection in blood donors. In screening for HBV infection, the blood donors who were negative for HBsAg marker could be identified through anti-HBc antibody test. The importance of anti-HBc antibody testing remains the main strategy to identify donors with occult HBV infection.

Acknowledgements The authors would like to thank the staff in the Basra blood bank and in the Al-Qurna blood bank for their help. They would also like to thank the donors for their kind support and participation throughout the study.

Contributors AA-R was responsible for developing initial drafts of the manuscript, designing the study, obtaining funding, data collection and analysis and final approval of the study. ZT contributed to the collection and assembly of data and final approval of the article. LA contributed to the design of the study, as well as to the critical revision of all drafts of the manuscript and data analysis.

Competing interests None declared.

Provenance and peer review Not commissioned; externally peer reviewed.

Data sharing statement No additional data are available.

Open Access This is an Open Access article distributed in accordance with the Creative Commons Attribution Non Commercial (CC BY-NC 4.0) license, which permits others to distribute, remix, adapt, build upon this work noncommercially, and license their derivative works on different terms, provided the original work is properly cited and the use is non-commercial. See: http:// creativecommons.org/licenses/by-nc/4.0/

\section{REFERENCES}

1. Lavanchy D. Hepatitis B virus epidemiology, disease burden, treatment, and current and emerging prevention and control measures. J Viral Hepat 2004;11:97-107.
2. Schmidt $M$, Nübling $\mathrm{CM}$, Scheiblauer $\mathrm{H}, \mathrm{t}$ al. Anti-HBc screening of blood donors: a comparison of nine anti-HBc tests. Vox Sang 2006;91:237-43.

3. Lok AS, McMahon BJ, Practice Guidelines Committee, American Association for the Study of Liver Diseases. Chronic hepatitis B. Hepatology 2001;34:1225-41.

4. Allain JP, Mihaljevic I, Gonzalez-Fraile MI, et al. Infectivity of blood products from donors with occult hepatitis $B$ virus infection. Transfusion 2013:53:1405-15.

5. Japhet MO, Adesina OA, Donbraye E, et al. Hepatitis B core IgM antibody (anti-HBclgM) among hepatitis B surface antigen ( $\mathrm{HBsAg}$ ) negative blood donors in Nigeria. Virol $J$ 2011;8:513.

6. Gish RG, Given BD, Lai CL, et al. Chronic hepatitis B: virology, natural history, current management and a glimpse at future opportunities. Antiviral Res 2015;121:47-58.

7. Ataallah TM, Hanan KA, Maysoun KS, et al. Prevalence of hepatitis $\mathrm{B}$ and $\mathrm{C}$ among blood donors attending the National Blood Transfusion Center in Baghdad, Iraq from 2006-2009. Saudi Med J 2011;32:1046-50.

8. Al-Juboury AWF, Salih HA, Al-Assadi MK, et al. Seroprevalance of hepatitis $\mathrm{B}$ and $\mathrm{C}$ among blood donors in Babylon Governorate- Iraq. Med J Babylon 2010;7:1-2.

9. Mühlbacher A, Zdunek D, Melchior W, et al. Is infective blood donation missed without screening for antibody to hepatitis $B$ core antigen and/or hepatitis B virus DNA? Vox Sang 2001;81:139.

10. Hennig H, Puchta I, Luhm J, et al. Frequency and load of hepatitis B virus DNA in first-time blood donors with antibodies to hepatitis $B$ core antigen. Blood 2002;100:2637-41.

11. Weber B, Melchior W, Gehrke R, et al. Hepatitis B virus markers in anti-HBc only positive individuals. J Med Virol 2001;64:312-19.

12. Grob $\mathrm{P}$, Jilg W, Bornhak $\mathrm{H}$, et al. Serological pattern "anti-HBc alone": report on a workshop. J Med Virol 2000;62:450-5.

13. Allain JP. Occult hepatitis B virus infection: implications in transfusion. Vox Sang 2004;86:83-91.

14. Su FH, Bai CH, Chu FY, et al. Significance and anamnestic response in isolated hepatitis $B$ core antibody-positive individuals 18 years after neonatal hepatitis $B$ virus vaccination in Taiwan. Vaccine 2012;30:4034-9.

15. Kurdi M, Abughararah M, Mulike M. Molecular detection of hepatitis $B$ virus (HBV) among voluntary ELISA positive blood donors in Almadinah Almunawwarah. J Taibah Univ Med Sci 2014;9:16670.

16. Chaudhuri V, Nanu A, Panda SK, et al. Evaluation of serologic screening of blood donors in India reveals a lack of correlation between anti-HBc titer and PCR-amplified HBV DNA. Transfusion 2003:43:1442-8.

17. Kaminski G, Alnaqdy A, Al-Belushi I, et al. Evidence of occult hepatitis $B$ virus infection among Omani blood donors: a preliminary study. Med Princ Pract 2006;15:368-72.

18. Mahmood AK, Addose SA, Salih HA, et al. Seroprevalence of HBs $\mathrm{ag}$ and Anti HCV positive blood donors in Najaf governorate. Iraqi $J$ Community Med 2001:14:29-33.

19. Ameen R, Sanad N, Al-Shemmari S, et al. Prevalence of viral markers among first-time Arab blood donors in Kuwait. Transfusion 2005;45:1973-80.

20. Al-Gani EA. Prevalence of HBV, HCV and HIV-1, 2 infections among blood donors in Prince Rashed Ben Al-Hassan Hospital in North Region of Jordan. Int J Biol Med Res 2011;2:912-16.

21. Hope VD, Eramova I, Capurro D, et al. Prevalence and estimation of hepatitis B and C infections in the WHO European Region: a review of data focusing on the countries outside the European Union and the European Free Trade Association. Epidemiol Infect 2014;142:270-86. 